\title{
Electrical Conductivity Test for Measurement of White Clover
} Seeds Vigor

\author{
Lucian A. dos Santos ${ }^{1}$, Ivan R. Carvalho ${ }^{1}$, Carolina C. Pinto ${ }^{1}$, Vinícius J. Szareski ${ }^{1}$, Jainara F. Netto ${ }^{1}$, \\ Letícia R. de Medeiros ${ }^{1}$, Andréa B. N. Martins ${ }^{1}$, Nairiane dos S. Bilhalva ${ }^{2}$, Priscila M. Marchi ${ }^{1}$, \\ João R. Pimentel ${ }^{1}$, Cristian Troyjack ${ }^{1}$, Géri E. Meneghello ${ }^{1}$, Lilian V. M. de Tunes ${ }^{1}$, Tiago Z. Aumonde ${ }^{1}$, \\ Tiago Pedo ${ }^{1} \&$ Francisco A. Villela ${ }^{1}$ \\ ${ }^{1}$ Department of Plant Science, Federal University of Pelotas, Capão do Leão, RS, Brazil \\ Correspondence: I. R. Carvalho, Department of Plant Science, Federal University of Pelotas, Eliseu Maciel \\ Avenue, No.96160000, Capão do Leão, RS, Brazil. E-mail: carvalho.irc@gmail.com
}

Received: August 6, $2018 \quad$ Accepted: February 15, $2019 \quad$ Online Published: July 31, 2019
doi:10.5539/jas.v11n12p40
URL: https://doi.org/10.5539/jas.v11n12p40

\begin{abstract}
This study aimed to evaluate the physiological performance of white clover seed lots of different tegument colours, besides to analyses the electrical conductivity test methodology with different seeds number, water volume and soaking periods. The experiment was developed at the Seed Didactic Laboratory in the Agronomy College "Eliseu Maciel" at the Federal University of Pelotas, in Pelotas-RS, Brazil. White clover seeds were manually separate, composing four lots of different coloured seeds: yellow, orange, brown and mixed. White clover seeds of yellow colour tend to present greater physiological potential through its germination and vigour. The electrical conductivity test was not efficient on identifying different vigour levels in white clover seed lots.
\end{abstract}

Keywords: Trifolium repens L., production of seeds, fodder, integration

\section{Introduction}

The white clover (Trifolium repens L.), belonging to Fabaceae family, is a winter perennial forage legume of great importance for animals diet, due to its significant improvement on the pasture nutritional quality (Olivo et al., 2012).

This species has uneven flowering, resulting in plants with tegument of seeds ranging from yellow to brown-red colour, because of the different ripening stages of seeds at harvest (Costa et al., 2014). After physiological maturity, photoassimilates from mother plant stop been sent to seeds; and the longer the time that seeds remain in field, will be more exposed to environment adversities, risking physiological quality losses (Szareski et al., 2017; Troyjack et al., 2018; Zanatta et al., 2018).

It is worth to mention that white clover seeds have different tegument colours, due to its genetic makeup and seeds age, in way that along the seeds lot ageing, the yellow colored seeds proportion reduces and the amount of brown colored seeds increases (West \& Harris, 1963).

In this way, seeds harvested just after achieve the physiological maturity present greater vigour, and high vigorous seeds origin better growing plants, with higher yield, compared to plants originated from low vigour seeds (Batista et al., 2015; Monteiro et al., 2016; Abati et al., 2017; Szareski et al., 2018).

The germination test is routinely carried at undertaking producing seeds laboratories, in order to evaluate the seed lots quality. However, laboratory testspresent ideal conditions (Delazeri et al., 2016; Rigo et al., 2018), differently from what occurs on the field when seeds are planted, where conditions may be adverse, revealing inferior germination rates (Grzybowski et al., 2015; Gehlling et al., 2018).

In this respect, vigour tests are important to supplement the standard germination test information, allowing provide accurate information about quality discrepancies of commercial seed lots, with the aim of check which one seed lot presents higher storage prospective and better performance at field (Marcos Filho, 2015a).

Seeds vigour is closely related to the cell membrane system integrity. In this way, less vigorous seeds present slower recoveringof cells membrane system during soaking. As consequence, there will be more electrolyte leakage for the incubation medium, and as higher the electrical conductivity values, the less vigour of seed lots 
(Silva et al., 2014; Marcos Filho, 2015a). The electrical conductivity test is fast, efficient and straightforward on the evaluation of seed lots vigour (Pereira \& Martins Filho, 2012). Several factors, such as seeds amount, water volume, hydration temperature, among others, may affect the test results; so, to obtain reliable information, these factors must to be studied.

An adequate methodology of electrical conductivity test has been studied for several crop species, such as Piptadenia moniliformis Benth (Pereiraet al., 2015), Crambea byssinica Hochst (Lima et al., 2015), Coriandrum sativum (Torres et al., 2015), among others, in order to verify its efficiency on detection of differences in vigour of seed lots, what demonstrate that the test is viable.

There is little information available about adequate methodology for evaluation of small seed lots, like white clover. Therefore, this study aimed to evaluate the physiological performance of white clover seed lots of different tegument colours, besides to analyses the electrical conductivity test methodology with different seeds number, water volume and soaking periods.

\section{Material and Methods}

The experiment was developed at the Seed Didactic Laboratory in the Agronomy College "Eliseu Maciel" at the Federal University of Pelotas, in Pelotas-RS, Brazil. White clover seeds were manually separate, composing four lots of different coloured seeds: yellow, orange, brown and mixed. Seeds colour was determined through the pixels intensity respectively of each seed colour, with a Konica Minolta colorimeter, CR-310 model, according to Table 1.

Table 1. Characterization of pixels intensity for each red (R), green (G), blue (B) and average colour component, in White clover seed lots of different colours

\begin{tabular}{lllll}
\hline Colour & R & G & B & Average \\
\hline Mixed & 115 & 92 & 34 & 80 \\
Brown & 96 & 66 & 33 & 65 \\
Orange & 113 & 90 & 32 & 78 \\
Yellow & 148 & 135 & 37 & 107 \\
\hline
\end{tabular}

The following traits were as sessed:

Water content: determinate in oven at $105 \pm 3{ }^{\circ} \mathrm{C}$ for 24 hours, according to Rules for Seed Analysis (MAPA, 2009), results expressed as percentage.

Germination: performed in four subsamples of germination boxes containing 50 seeds each, which were kept in a B.O.D. (Biochemical Oxygen Demand) germination camera at $20^{\circ} \mathrm{C}$. Two assessments were made, four and ten days after sowing, measuring the percentage of normal seedlings (MAPA, 2009).

First germination count: carried out four days after sowing, simultaneously to the standard germination test, according to MAPA (2009), results as percentage.

Percentage of abnormal seedling, hard seeds and dead seeds: performed at the last counting of the germination test (ten days after sowing), measuring the fraction of each one of these classes, as percentage.

Seedlings emergence: developed in soil and substrate beds. Four subsamples of 50 seeds were sown at a depth of $1 \mathrm{~cm}$, spaced by $2 \mathrm{~cm}$ from each other. The beds were manually irrigated whenever necessary. The counting of emerged seedlings was assessed 21 days after sowing, results as percentage.

Emergence Speed Index (ESI): conduced with the field emergence test. Counts were performed daily, from de beginning of seedlings emergence until the number of seedlings was stabilized. The ESI was calculated according to Maguire (1962).

Electrical conductivity: a mass method was applied, according to Vieira and Krzyzanowski (1999), in which combinations among seeds quantity (25 and 50$)$ and deionized water volume $(25,50$ and $75 \mathrm{~mL})$ were analyzed. The seeds were weighed on an analytical balance ( $0.0001 \mathrm{~g}$ readability); then placed in plastic cups, which ones were kept in B.O.D. germination camera at $25^{\circ} \mathrm{C}$. The measurements were performed 1, 3, 6 and 24 hours after soaking, with a conductivity meter (Digimed DM-32). The results were expressed as $\mu \mathrm{S} \mathrm{cm}^{-1} \mathrm{~g}^{-1}$.

The experimental design was completely randomized with five replications for the physiological quality test and for electrical conductivity test. The electrical conductivity test had a factorial arrange $(4 \times 6)$, with four seed 
colours (yellow, orange, brown and mixed) and six combination among seeds number and deionized water volume (50_75; 50_50; 50_25;25_75;25_50;25_25).

The data expressed in percentage were transformed using ArcSenRaiz(x/100), but the real means were presented. The analysis of variance was carried out and the treatment means were compared by the Tukey's test at 5\% probability.

\section{Results and Discussion}

The analysis of variance detected differences $(\mathrm{P} \leq 0.05)$ for the traits germination, first germination count, abnormal seedling, hard seeds, dead seeds, seedlings emergence and emergence speed index (Table 2). The electrical conductivity test did not present interaction between the factors seed colour and SN/WV (seeds number/deionized water volume) at one, six or 24 hours of soaking (Table 3); however, at three hours of soaking the factors presented interaction (Table 4).

Seeds water content was similar among the four lots of different seed colours, with $8 \%$ in mixed coloured seeds, $7.9 \%$ for brown seeds, $8.1 \%$ for orange seeds and $8.2 \%$ for yellow seeds (Table 2). Based on these results, the seeds water content of the different lots did not influence on the results of all the analyzed tests, since the variation obtained was lower than $2 \%$, which is considered the acceptable limit (Marcos Filho, 2015b). Seed lots with similar water content are fundamental to obtain efficient results from vigor tests (Marcos Filho, 1999).

Table 2. Physiological quality characterization of white clover seed lots of different colours, by the germination test $(\mathrm{G})$, first germination count (FC), seedlings emergence (E), emergence speed index (ESI), percentage of abnormal plants (A), percentage of hard seeds $(\mathrm{H})$ and percentage of dead seeds (D)

\begin{tabular}{|c|c|c|c|c|c|c|c|c|}
\hline Colour & $\mathrm{U}$ & G & FC & A & $\mathrm{H}$ & $\mathrm{D}$ & $\mathrm{E}$ & ESI \\
\hline & \multicolumn{8}{|c|}{------------------------------------------------------- $\%$------------------------------------------------------ } \\
\hline Mixed & 8.0 & $89 \mathrm{ab}^{*}$ & $79 \mathrm{ab}$ & $4.5 \mathrm{~b}$ & $4.0 \mathrm{a}$ & $2.5 \mathrm{ab}$ & $84 \mathrm{~b}$ & $6.80 \mathrm{ab}$ \\
\hline Brown & 7.9 & $88 \mathrm{~b}$ & $79 \mathrm{ab}$ & $2.0 \mathrm{~b}$ & $5.5 \mathrm{a}$ & $4.5 \mathrm{a}$ & $83 \mathrm{~b}$ & $6.59 \mathrm{~b}$ \\
\hline Orange & 8.1 & $88 \mathrm{~b}$ & $72 b$ & $3.5 \mathrm{ab}$ & $5.0 \mathrm{a}$ & $3.5 \mathrm{a}$ & $85 \mathrm{~b}$ & $7.06 \mathrm{ab}$ \\
\hline Yellow & 8.2 & $96 a$ & $84 \mathrm{a}$ & $0.5 \mathrm{c}$ & $3.0 \mathrm{~b}$ & $0.5 \mathrm{~b}$ & $95 \mathrm{a}$ & $7.79 \mathrm{a}$ \\
\hline $\mathrm{CV}(\%)$ & - & 4.35 & 7.14 & 31.58 & 55.30 & 40.65 & 2.77 & 8.80 \\
\hline
\end{tabular}

Note. * Means followed by the same letter in the columns are not different by Tukey test, at $5 \%$ probability. CV $(\%)=$ coeficient of variation.

Greater germination percentage was observed for the yellow seeds lot $(96 \%)$, while the brown and the orange seeds lots presented the same percentage of germination, $88 \%$ (Table 2). Although the lots of colours presented differences for the germination percentage, all the results are higher then $80 \%$, the minimum required for white clover seeds commercialization (MAPA, 2016).

These results corroborate with Dalanhol et al. (2014), which evaluated physiological quality of three Bowdichia virgilioides Kunth seed lots of different colours, and observed that the yellow seeds lot presented greater percentage of germination (98\%), while the lot with orange and red seeds presented $85.3 \%$ and $31.3 \%$ of germination, respectively. The germination test is performed in optimal conditions, that's why it is not sensitive to detect small variation of vigour in the seed lots (Marcos Filho, 1999); nevertheless, in this study, the test ranked the lots in different germination levels.

The results observed at the first germination count indicate that the yellow seeds lot presented greater vigour (84\%), while the orange seeds lot revealed lower vigour (72\%) (Table 2). According to Torres et al. (2015), this test is sensitive to detect differences on vigour of Coriandrum sativum L. seeds lots. The utilization of this test to evaluate vigour of seed lots is due to its efficiency in identifying lots with higher fast establishment capacity, in addition to be less demanding, since is conduced simultaneously to the germination test, dismissing the use of special equipment (Nakagawa, 1999; Torres et al., 2015).

In respect to the percentage of abnormal plants, the lot of yellow seeds presented lower values $(0.5 \%)$, while the lot of mixed coloured seeds presented the higher percentage of abnormal seedlings (4.5\%) (Table 2). For the percentage of hard seeds, the lot of yellow seeds presented the lower mean $(3.0 \%)$, differing from the lots of mixed coloured seeds, brown seeds and orange seeds (4.0, 5.5 and 5.0\%, respectively), which ones were similar. The lot of yellow seeds presented the lower percentage of dead seeds $(0.5 \%)$, similarly to the lot of mixed 
coloured seeds (2.5). The lots of brown and orange seeds were similar to the lot of mixed seeds, but different from the lot of yellow seeds, with higher percentage of dead seeds (4.5 and 3.5\%, respectively).

White clover seeds have dormancy due to the existence of a water impermeable layer on seed coat (also termed 'hard' seed). This structure inhibits water permeability, preventing the beginning of germination process (Mittelmann et al., 2012). In this context, it can be affirmed that, on 'hard' seeds, do not occurs or rarely occurs the soaking process. Thus, electrolyte leakage for the incubation medium may be affected, hiding electrical conductivity test results, mistaking the vigour of seed lots assessed. In this study low percentages of hard seeds were observed, because seeds remained in cold storage for enough time to break its dormancy.

The field emergence test revealed a ranking of different vigour levels for the seed lots. The lot of yellow seeds presented greater percentage of emergence (95\%), differing from the lots of mixed coloured seeds $(84 \%)$, brown seeds (83\%) and orange seeds (85\%) (Table 2). These results agree with Torres et al. (2015), which observed that the emergence test was sensitive to classify lots of Coriandrum sativum L seeds, cultivars 'Português', 'Super Verdão' and 'Verdão', in three different vigour levels. The seedlings emergence test is an indicator parameter oftests efficiency to evaluate physiological potential of seed lots (Marcos Filho, 1999). The results of a vigour test have been tightly related to the field emergence test, so that can be considered efficient (Marcos Filho, 2015a; Szareski et al., 2017).

With regard to the emergence speed index, the lot of yellow seeds presented higher value (7.78), similarly to the lots of mixed coloured seeds (6.80) and orange seeds (7.06), while the lot of brown seeds revealed lower emergence speed index (6.59). This index is a method to measure seeds vigour, and the advantage is due the similar conditions to field in which this test is performed. The vigour is evaluated through emergence speed of seeds at field conditions, so, the faster the seedlings emergence, the greater the vigour (Oliveira et al., 2009). Higher emergence speed index indicate greater seeds vigour (Marcos Filho, 2015b).

Generally speaking, it is possible to observe that the lot of yellow seeds presents higher percentage of germination and vigour (Table 2). White clover seeds have uneven ripeness, resulting in plants with tegument colour variation, ranging from yellow to brown-red (Costa et al., 2014). According to Dalanhol et al. (2014), the same occurs with Bowdichia virgilioides Kunth seeds, and the tegument colour variation is closely related to physiological quality of seed lots. Atis et al. (2011) observed that tegument colour of red clover (Trifolium pratense) seeds may indicate their quality, and greater germination and vigour values were found for yellow seeds.

Probably, the yellow seeds achieve physiological ripeness near the harvest, in comparison to seeds of other colour; therefore, yellow seeds are younger than seeds of other colours, what provides greater germination potential and vigour (Marcos Filho, 2015b). It can be explained due to the fact that, at the physiological ripeness, occurs biosynthesis and deposition of storage compounds, like lipids, proteins and carbohydrates, which ones will work as energy source for seeds germination and seedlings early growth (Bewley et al., 2013; Marcos Filho, 2015b). In contrast, lower physiological quality observed for the other lots of seeds can be resulting from a deterioration process, responsible for reducing seeds vigour and their physiological quality (Marcos Filho, 2015a).

The electrical conductivity test did not reveal interaction between the factors seed colour and SN/WV (seeds number/deionized water volume) at one, six or 24 hours of soaking; so, the factors were sliced separately and results are presented in Table 3. 
Table 3. Seed colour and SN/WV factors sliced for the values of electrical conductivity test $\left(\mu \mathrm{S} \mathrm{cm}^{-1} \mathrm{~g}^{-1}\right)$ from 25 and 50 white clover seeds, with soaking in 25,50 and $75 \mathrm{~mL}$ of deionized water, for the soaking periods of one, six and 24 hours

\begin{tabular}{llll}
\hline Colour & $1 \mathrm{~h}$ & $6 \mathrm{~h}$ & $24 \mathrm{~h}$ \\
\hline Mixed & $123.30 \mathrm{a}^{*}$ & $261.38 \mathrm{a}$ & $429.11 \mathrm{a}$ \\
Brown & $109.75 \mathrm{ab}$ & $227.79 \mathrm{bc}$ & $398.38 \mathrm{a}$ \\
Orange & $108.28 \mathrm{ab}$ & $230.05 \mathrm{~b}$ & $412.66 \mathrm{a}$ \\
Yellow & $85.94 \mathrm{~b}$ & $199.70 \mathrm{c}$ & $403.28 \mathrm{a}$ \\
\hline SN/WV & & & \\
\hline $50 \_75$ & $72.77 \mathrm{bc}$ & $138.48 \mathrm{~cd}$ & $237.36 \mathrm{~d}$ \\
$50 \_50$ & $86.45 \mathrm{~b}$ & $180.38 \mathrm{~b}$ & $365.61 \mathrm{c}$ \\
$50 \_25$ & $185.86 \mathrm{a}$ & $388.49 \mathrm{a}$ & $704.51 \mathrm{a}$ \\
$25 \_75$ & $52.67 \mathrm{c}$ & $117.84 \mathrm{~d}$ & $227.29 \mathrm{~d}$ \\
$25 \_50$ & $75.76 \mathrm{bc}$ & $176.56 \mathrm{bc}$ & $328.10 \mathrm{c}$ \\
$25 \_25$ & $167.41 \mathrm{a}$ & $376.62 \mathrm{a}$ & $602.00 \mathrm{~b}$ \\
CV $(\%)$ & 30.18 & 17.25 & 10.99 \\
\hline
\end{tabular}

Note. * Means followed by the same letter in the columns are not different by Tukey test, at $5 \%$ probability. CV $(\%)=$ coefficient of variation.

At the period of one hour of soaking, there were a ranking of seed lots of different colours in relation to the vigour (Table 3). Yellow seeds presented greater vigour, while mixed coloured seeds presented lower vigour. These results are not consistent with those obtained from the emergence test (Table 2).

For the six hours of soaking period, yellow seeds presented greater vigour again, and mixed coloured seeds presented lower vigour (Table 3); however, these results are not similar to what occurred in the emergenece test (Table 2).

In relation to the 24 hours of soaking period, vigour did not differ among seed lots of different colours (Table 3 ). It colud be due to the resorption of electrolytes released from seeds to the soaking solution; because there is a tendency to achieve a balance between seeds and the solution surrounding (Flávio \& Paula, 2010).

Electrical conductivity tests measure the electrolytes amount that leak form seeds to external medium. In this way, as higher the rearranging capacity of seeds membranes, the lower will be the electrical conductivity value, consequently, greater seeds vigour; and as lower the rearranging capacity of seeds membranes, the higher will be the electrical conductivity value, and lower the seeds vigour (Marcos Filho, 2015a; Peske et al., 2012).

The combination of factors seeds number and deionized water volume (SN/WV), at one hour of soaking, revealed that the combination of 25 seeds with $75 \mathrm{~mL}$ of water provided lower electrical conductivity value; however, this value was similar to the combinations of 50 seeds with $75 \mathrm{~mL}$ of water and 25 seeds with $50 \mathrm{~mL}$ of water (Table 3). For the combination 50 seeds with $50 \mathrm{~mL}$ of water, the electrical conductivity value was moderate, and similar to those observed for the combinations 50 seeds with $75 \mathrm{~mL}$ of water and 25 seeds with $50 \mathrm{~mL}$ of water. The combinations 25 seeds with $25 \mathrm{~mL}$ of water, and 50 seeds with $25 \mathrm{~mL}$ of water presented higher electrical conductivity values, not differing among each other (Table 3 ).

For the period of six hours soaking, the combination 25 seeds with $75 \mathrm{~mL}$ of water resulted in lower electrical conductivity value, similarly to the combination 50 seeds with $75 \mathrm{~mL}$ of water (Table 3). For the combination 50 seeds with $50 \mathrm{~mL}$ of water, moderate value of electrical conductivity, been similar to the observed for the combination 25 seeds with $50 \mathrm{~mL}$ of water. The higher values were observed for the combinations 25 seeds with $25 \mathrm{~mL}$ of water, and 50 seeds with $25 \mathrm{~mL}$ of water (Table 3 ).

At the period of 24 hours of soaking, the combinations 50 seeds with $75 \mathrm{~mL}$ of water and 25 seeds with $75 \mathrm{~mL}$ of water presented the lower values of electrical conductivity (Table 3); while the combinations 50 seeds with 50 $\mathrm{mL}$ of water and 25 seeds with $50 \mathrm{~mL}$ of water revealed intermediate value; and the combination 50 seeds with $25 \mathrm{~mL}$ of water presented higher value of electrical conductivity, followed by the combination 25 seeds with 25 $\mathrm{mL}$ of water.

The results observed in this study confirm that water volume increasing during seeds soaking reduces the results of electrical conductivity test, what corroborate with the results obtained for Sesam umindicum seeds (Torres et 
al., 2009), for Bowdichia virgilioides Kunth seeds (Dalanhol et al., 2014) and for yellow passionfruit (Passifloraedulis) seeds (Barbosa et al., 2012).

For the period of three hours of soaking, the factors seeds colour and the combinations of seeds number and deionized water volume (SN/WV) revealed interaction (Table 4). For the factor seeds colour, only the combination of 50 seeds with $25 \mathrm{~mL}$ of water presented difference, and yellow seeds presented lower electrical conductivity values; while the lots of brown and orange seeds revealed moderate values; and the lot of mixed coloured seeds presented higher values of electrical conductivity. The other combinations did not present difference (Table 4).

Table 4. Electrical conductivity $\left(\mu \mathrm{S} \mathrm{cm}^{-1} \mathrm{~g}^{-1}\right.$ ) of 25 and 50 white clover seeds of different colours, immersed in 25,50 and $75 \mathrm{~mL}$ of deionized water, for three hours of soaking

\begin{tabular}{lllllll}
\hline Colour & $50 \_75$ & $50 \_50$ & $50 \_25$ & $25 \_75$ & $25 \_50$ & $25 \_25$ \\
\hline Mixed & $118.16 \mathrm{aB}$ & $160.96 \mathrm{aB}$ & $318.17 \mathrm{aA}$ & $84.79 \mathrm{aB}$ & $137.06 \mathrm{aB}$ & $280.76 \mathrm{aA}$ \\
Brown & $136.90 \mathrm{aC}$ & $141.20 \mathrm{aC}$ & $205.76 \mathrm{bB}$ & $94.20 \mathrm{aC}$ & $142.72 \mathrm{aC}$ & $271.02 \mathrm{aA}$ \\
Orange & $96.50 \mathrm{aB}$ & $139.53 \mathrm{aB}$ & $239.50 \mathrm{bA}$ & $100.97 \mathrm{aB}$ & $122.76 \mathrm{aB}$ & $264.74 \mathrm{aA}$ \\
Yellow & $87.94 \mathrm{aC}$ & $114.23 \mathrm{aC}$ & $178.91 \mathrm{cB}$ & $87.74 \mathrm{aC}$ & $113.61 \mathrm{aC}$ & $249.74 \mathrm{aA}$ \\
\hline CV $(\%)$ & 21.77 & & &
\end{tabular}

Note. * Means followed by the same letter in the columns and capital letter in the rows are not different by Tukey test, at $5 \%$ probability. CV $(\%)=$ coefficient of variation.

Regarding to the factor seeds number/water volume, for the mixed and orange seeds, the use of 25 seeds in 25 $\mathrm{mL}$ of water and 50 seeds in $25 \mathrm{~mL}$ of water achieved higher electrical conductivity values, and the other combinations were similar among each other, with lower values (Table 4).

For the lots of brown and yellow seeds, the combination performed by 25 seeds with $25 \mathrm{~mL}$ of water revealed higher electrical conductivity value, followed by the combination 50 seeds with $25 \mathrm{~mL}$ of water. The other combinations were similar among each other, with lower values (Table 4).

Based on this study's results, it is possible to observe a relation between deionized water volume and seeds electrical conductivity. So, as higher the water volume used, the lower the seeds electrical conductivity, independent from seeds number. These results are similar to reported by Lopes et al. (2010), which revealed that electrical conductivity of ryegrass (Lolium multiflorum) seeds was higher when lower water volume was used to perform the test than higher water volume. In addition, Lopes et al. (2012) observed higher electrical conductivity of jilo (Solanum aethiopicum) seeds when seeds were immersed in lower water volume. This can be explained because by reducing water volume, solutes concentration in the medium is increased, resulting in higher electrical conductivity (Torres et al., 2015).

The increase of seeds number, setting the water volume, provides increase of electrical conductivity value (Tables 3 and 4). Pereira et al. (2015) observed the same, what means, the electrical conductivity value increased when a higher number of seeds was used in the test. However, Lopes et al. (2010) did not observed electrical conductivity increasing by increasing seeds number.

The correlation analysis (Table 5) revealed that the electrical conductivity test, performed with the combinations of 25 seeds with $50 \mathrm{~mL}$ of water, and 25 seeds with $75 \mathrm{~mL}$ of water, in one hour on soaking, presented negative significant correlation to the seedlings emergence test (Table 2). For the soaking period of three hours, the combination of 50 seeds with $75 \mathrm{~mL}$ of water was negatively correlated to the seedlings emergence. For the six hours of soaking, the combinations of 50 seeds with $75 \mathrm{~mL}$ of water and 25 seeds with $75 \mathrm{~mL}$ of water were negatively correlated to the seedlings emergence. The soaking period of 24 hours was not significant correlated (Table 5). These results are similar to observed by Torres et al. (2015) and Araujo et al. (2011), which evaluated Coriandrum sativum and Vigna radiate seeds, respectively, and revealed that electrical conductivity was significant correlated to the seedlings emergence test. 
Table 5. Coefficients of Pearson linear correlation between the results from the electrical conductivity test and the results from the seedlings emergence test $(\mathrm{E} \%)$, in white clover seed lots of different colours

\begin{tabular}{|c|c|c|c|c|}
\hline \multicolumn{5}{|c|}{ Electrical conductivity } \\
\hline & 1 hour & 3 hours & 6hours & 24 hours \\
\hline \multicolumn{5}{|c|}{50 seeds $/ 75 \mathrm{~mL}$} \\
\hline $\mathrm{E} \%$ & $-0.4437^{\mathrm{ns}}$ & $-0.4495^{*}$ & $-0.5048^{*}$ & $-0.4223^{\mathrm{ns}}$ \\
\hline \multicolumn{5}{|c|}{50 seeds $/ 50 \mathrm{~mL}$} \\
\hline $\mathrm{E} \%$ & $-0.3437^{\mathrm{ns}}$ & $0.3729^{\mathrm{ns}}$ & $-0.3948^{\mathrm{ns}}$ & $-0.2869^{\mathrm{ns}}$ \\
\hline \multicolumn{5}{|c|}{50 seeds $/ 25 \mathrm{~mL}$} \\
\hline $\mathrm{E} \%$ & $-0.3151^{\mathrm{ns}}$ & $-0.3347^{\mathrm{ns}}$ & $-0.4493 *$ & $-0.3564^{\mathrm{ns}}$ \\
\hline \multicolumn{5}{|c|}{25 seeds $/ 75 \mathrm{~mL}$} \\
\hline $\mathrm{E} \%$ & $0.3946^{\mathrm{ns}}$ & $0.0828^{\mathrm{ns}}$ & $0.0853^{\mathrm{ns}}$ & $0.1027^{\mathrm{ns}}$ \\
\hline \multicolumn{5}{|c|}{25 seeds $/ 50 \mathrm{~mL}$} \\
\hline $\mathrm{E} \%$ & $-0.4909 *$ & $-0.1990^{\mathrm{ns}}$ & $-0.1170^{\mathrm{ns}}$ & $0.1431^{\mathrm{ns}}$ \\
\hline \multicolumn{5}{|c|}{25 seeds $/ 25 \mathrm{~mL}$} \\
\hline $\mathrm{E} \%$ & $-0.4802 *$ & $-0.3103^{\mathrm{ns}}$ & $-0.3189^{\mathrm{ns}}$ & $-0.1853^{\mathrm{ns}}$ \\
\hline
\end{tabular}

Note. ${ }^{\text {ns }}$ Non-significant values; $*$ Significant values at $1 \%$ probability.

The negative values obtained from correlation analysis can be explained because traits assessed presents opposite directions, in other words, as higher the seeds vigour, the lower is the electrical conductivity (Nogueira et al., 2013), what mean that they are inverse proportion.

In order to establish an adequate methodology to perform the electrical conductivity test, it is very important that data obtained from this test are correlated to values obtained from the seedlings emergence test, and a ranking from the seed lots in different vigour levels, proportionally to the seedlings emergence test, has to occurs (Marcos Filho, 2009; Torres et al., 2015; Pedó et al., 2016; Soares et al., 2016).

In this context, it is important to highlight that, in the present study, despite having significant correlation for some combinations (Table 5) between the electrical conductivity test and seedling emergence, it was not observed a vigour ranking of seed lots of different colours obtained from electrical conductivity test corresponding to the observed by the emergence test. Thus, the methodology used in this study to perform the electrical conductivity test was no adequate to evaluate vigour of white clover seeds (Tables 2, 3 and 4). This results are different from those reported about Coriandrum sativum seeds (Torres et al., 2015), Sesam umindicum seeds (Torres et al., 2009), and raygrass (Lolium multiflorum) seeds (Lopes et al., 2010), in which the electrical conductivity test was efficient to ranking seed lots of these species in different vigour levels.

\section{Conclusion}

White clover seeds of yellow colour tend to present greater physiological potential through its germination and vigour. The electrical conductivity test was not efficient on identifying different vigour levels in white clover seed lots.

\section{Acknowledgements}

We thank the National Council for Scientific and Technological Development (CNPq) and the Coordination for the Improvement of Higher Education Personnel (CAPES) for granting scholarships.

\section{References}

Abati, J., Brzezinski, C. R., Simoneti Foloni, J. S., Zucareli, C., Bassoi, M. C., \& Henning, F. A. (2017). Seedling emergence and yield performance of wheat cultivars depending on seed vigor and sowing density. Journal of Seed Science, 39(1), 58-65. https://doi.org/10.1590/2317-1545v39n1171002

Araujo, R. F., Zonta, J. B., Araujo, E. F., Heberle, E., \& Zonta, F. M. G. (2011). Teste de condutividade elétrica para sementes de feijão-mungo-verde. Revista Brasileira de Sementes, 33(1), 123-130. https://doi.org/ $10.1590 / \mathrm{S} 0101-31222011000100014$

Atis, I., Atak, M., Can, E., \& Mavi, K. (2011). Seed Coat Color Effects on Seed Quality and Salt Tolerance of Red Clover (Trifolium pratense). International Journal of Agriculture and Biology, 13(3), 363-368. 
Barbosa, R. M., Silva, C. B., da Medeiros, M. A. de, Centurion, M. A. P. da, \& Vieira, R. D. (2012). Condutividade elétrica em função do teor de água inicial de sementes de amendoim. Ciência Rural, 42(1), 45-51. https://doi.org/10.1590/S0103-84782012000100008

Batista, T. B., Binotti, F. F. S., Cardoso, E. D., Bardiviesso, E. M., \& Costa, E. (2015). Aspectos fisiológicos e qualidade de mudas da pimenteira em resposta ao vigor e condicionamento das sementes. Bragantia, 74(4), 367-373. https://doi.org/10.1590/1678-4499.0133

Bewley, J. D., Bradford, K. J., Hilhorst, H. W. M., \& Nonogaki, H. (2013). Seeds: Physiology of development, germination and dormancy (3rd ed., p. 392). New York: Springer. https://oi.org/10.1007/ 978-1-4614-4693-4

Carvalho, I. R., Nardino, M., Demari, G. H., Szareski, V. J., Follmann, D. N., Pelegrin, A. J., ... Souza, V. Q. (2017). Relations among phenotypic traits of soybean pods and growth habit. African Journal of Agricultural Research, 12(6), 450-458. https://doi.org/10.5897/AJAR2016.11660

Costa, C. J., Martins, A. B. N., Ribeiro, P. R. G., Vaz, C. F., Silva, M. G., \& Franco, D. F. (2014). Coloração do Tegumento e Tolerância à Salinidade em Sementes de Trevo-Branco (p. 19). Boletim de Pesquisa e Desenvolvimento/EMBRAPA Clima Temperado. Pelotas, RS: EMBRAPA Clima Temperado.

Dalanhol, S. J., Rezende, E. H., Abreu, D. C. A. de, \& Nogueira, A. C. (2014). Teste de Condutividade Elétrica em Sementes de Bowdichia virgilioides Kunth. Floresta e Ambiente, 21(1), 69-77. https://doi.org/10.4322/ floram.2014.013

Delazeri, P., Garlet, J., \& Souza, G. F. (2016). Teste de Condutividade Elétrica em Lotes de Sementes de Schinus molle L. Floresta e Ambiente, 23(3), 413-417. https://doi.org/10.1590/2179-8087.142615

Flávio, J. J. P., \& Paula, R. C. (2010). Testes de envelhecimento acelerado e de condutividade elétrica em sementes de Dictyolom avandellianum A. Juss. Scientia Forestalis, 38, 391-399.

Gehlling, V. M., Segalin, S. R., Troyjack, C., Pimentel, J. R., Carvalho, I. R., Szareski, V. J., ... Aumonde, T. Z. (2018). Temporal Waterlogging and Physiological Performance of Wheat (Triticum aestivum L.) Seeds. Journal of Agricultural Science, 10(6), 363-371. https://doi.org/10.5539/jas.v10n6p363

Grzybowski, C. R. de S., Vieira, R. D., \& Panobianco, M. (2015). Testes de estresse na avaliação do vigor de sementes de milho. Revista Ciência Agronômica, 46(3), 590-596.

Lima, J. J. P., Freitas, M. N., Guimarães, R. M., Vieira, A. R., \& Ávila, M. A. B. (2015). Accelerated aging and electrical conductivity tests in crambe seeds. Ciência e Agrotecnologia, 39(1), 7-14. https://doi.org/10.1590/ S1413-70542015000100001

Lopes, M. M., Barbosa, R. M., \& Vieira, R. D. (2012). Methods for evaluating the physiological potential of scarletegg plant (Solanum aethiopicum) seeds. Seed Science and Technology, 40(1), 86-94. https://doi.org/ 10.15258/sst.2012.40.1.09

Lopes, R. R., \& Franke, L. B. (2010). Teste de condutividade elétrica para avaliação da qualidade fisiológica de sementes de azevém (Lolium multiflorum L.). Revista Brasileira de Sementes, 32(1), $123-130$. https://doi.org/10.1590/S0101-31222010000100014

Maguire, J. D. (1962). Speed of germination-aid selection and evaluation for seedling emergence and vigor. Crop Science, 2, 176-177. https://doi.org/10.2135/cropsci1962.0011183X000200020033x

MAPA (Ministério da Agricultura, Pecuária e Abastecimento). (2009). Regras para análise de sementes (p. 399). Secretaria Nacional de Defesa Agropecuária. Brasília, DF: MAPA/ACS.

MAPA (Ministério da Agricultura, Pecuária e Abastecimento). (2016). InstruçãoNormativa $\mathrm{n}^{\circ}-44$, de 22 Novembro de 2016.

Marcos Filho, J. (1999). Teste de envelhecimento acelerado. In F. C. Krzyzanowski, R. D. Vieira, \& J. B. França-Neto (Eds.), Vigor de sementes: conceitos e testes (Cap. 3, pp. 1-24). Londrina: ABRATES.

Marcos Filho, J. (2015). Fisiologia de Sementes de Plantas Cultivadas (2nd ed., p. 660). ABRATES, Londrina, PR.

Marcos Filho, J. (2015). Seed vigor testing: An overview of the past, present and future perspective. Scientia Agricola, 72(4), 363-374. https://doi.org/10.1590/0103-9016-2015-0007 
Marcos Filho, J., \& Novembre, A. D. L. C. (2009). Avaliação do potencial fisiológico de sementes de hortaliças. In W. M. Nascimento (Ed.), Tecnologia de sementes de hortaliças (pp. 185-246). Brasília, DF: EMBRAPA Hortaliças.

Mittelmann, A., Bortolini, F., Ferreira, O. G., Pedroso, C. E. S., Coelho, R. A. T., Fagundes, C. M., ... Fucilini, V. F. (2012). Características Fisiológicas de Sementes de Trevo-alexandrino e Trevo-vesiculoso e necessidade de Escarificação (pp. 1-4, Comunicado Técnico n 290). Pelotas, RS.

Monteiro, M. A., Aisenberg, G. R., Koch, F., Salau, G. M., Behenck, J. P. de O., Demari, G. H., ... Aumonde, T. Z. (2016). Yield and vigor of corn seeds under the influence of flooding periods. African Journal of Agricultural Research, 11, 3240-3245. https://doi.org/10.5897/AJAR2016.11367

Nakagawa, J. (1999). Testes de vigor baseados no desempenho das plântulas. In F. C. Krzyzanowski, R. D. Vieira, J. B. França Neto, \& P. R. Londrina (Eds.), Vigor de sementes: Conceitos e testes (Vol. 2, pp. 1-24). Londrina: ABRATES.

Nogueira, J. L., Silva, B. da, Carvalho, T. C. de, \& Panobianco, M. (2013). Teste de condutividade elétrica para avaliação do potencial fisiológico de sementes de aveia preta. Revista Ceres, 60(6), 896-901. https://doi.org/ 10.1590/S0034-737X2013000600019

Oliveira, A. C. S., Martins, G. N., Silva, R. F., \& Vieira, H. D. (2009). Testes de vigor em sementes baseados no desempenho de plântulas. Interscience Place, 1(4).

Olivo, C. J., Nörnberg, J. L., Meinerz, G. R., Agnolin, C. A., Machado, P. R., Marx, F. R., ... Santos, J. C. (2012) Produtividade e valor nutritivo de pastos consorciados com diferentes espécies de leguminosas. Ciência Rural, 42(11), 2051-2058. https://doi.org/10.1590/S0103-84782012005000098

Pedo, T., Koch, F., Delias, D. dos S., Aisenberg, G. R., Szareski, V. J., Carvalho, I. R., \& Aumonde, T. Z. (2016). Antioxidante enzyme activity and initial growth of wheat, rye and bean under soil flooding. International Journal of Current Research, 8(8), 36635-36642.

Pereira, K. T. O., Aquino, G. S. M., Alves, T. R. C., Benedito, C. P., \& Torres, S. B. (2015). Electrical conductivity test in Piptadenia moniliformis Benth. Seeds. Journal of Seed Science, 37(4), 199-205. https://doi.org/10.1590/2317-1545v37n4152357

Pereira, M. D., \& Martins Filho, S. (2017). Adequação da metodologia do teste de condutividade elétrica para sementes de cubiu (Solanum sessiliflorum DUNAL). Revista Agrarian, 5, 93-98.

Peske, S. T., Villela, F. A., \& Meneghello, G. E. (2012). Sementes: Fundamentos Científicos e Tecnológicos (3rd ed., p. 573). Pelotas, Brazil.

Rigo, G. A., Schuch, L. O. B., Vargas, R. L., Barros, W. S., Szareski, V. J., Carvalho, I. R., ... Pedo, T. (2018). Micronutrient Content and Physiological Quality of Soybean Seeds. Journal of Agricultural Science, 10(4), 223-230. https://doi.org/10.5539/jas.v10n4p223

Silva, V. N., Zambiasi, C. A., Tillmann, M. A. A., Menezes, N .L., \& Villela, F. A. (2014). Condução do teste de condutividade elétrica utilizando partes de sementes de feijão. Revista de Ciências Agrárias, 37(2), 206-213.

Soares, V. N., Szareski, V. J., Nardino, M., \& Souza, V. Q. D. (2016). Stress due to soil flooding and differential plysiological responses to initial growht of wheat plants. Australian Journal of Basic and Applied Sciences, 10, 260-266.

Szareski, V. J., Carvalho, I. R., Demari, G. H., Pelissari, G., Pelegrin, A. J., Barbosa, M. H., ... Aumonde, T. Z. (2018). Path analysis applied to agronomic traits of contrasting growth habit soybeans. Australian Journal of Crop Science, 12(4), 531-538. https://doi.org/10.21475/ajcs.18.12.04.pne608

Szareski, V. J., Carvalho, I. R., Kehl, K., Levien, A. M., Nardino, M, Dellagostin, S. M., ... Aumonde, T. Z. (2018). Evaluation of the adaptability and stability of wheat genotypes using a phenotypic index of seed vigor. Pesquisa Agropecuária Brasileira, 53(6), 727-735. https://doi.org/10.1590/S0100-204X2018000 600009

Szareski, V. J., Carvalho, I. R., Kehl, K., Levien, A. M., Nardino, M., Demari, G., ... Aumonde, T. Z. (2017). Univariate, multivariate techniques and mixed models applied to the adaptability and stability of wheat in the Rio Grande do Sul State. Genetics and Molecular Research, 16(3), 1-13. https://doi.org/10.4238/ gmr16039735 
Torres, S. B., Medeiros, M. A. de, Tosta, M. da S., \& Costa, G. M de M. (2009). Teste de condutividade elétrica em sementes de gergelim. Revista Brasileira de Sementes, 31(3), 070-077. https://doi.org/10.1590/ S0101-31222009000300008

Torres, S. B., Paiva, E. P., Almeida, J. P. N., Benedito, C. P., \& Carvalho, S. M. C. (2015). Teste de condutividade elétrica na avaliação da qualidade fisiológica de sementes de coentro. Revista Ciência Agronômica, 46(3), 622-629.

Troyjack, C., Pimentel, J. R., Dubal, I. P., Escalera, R. A. V., Jaques, L. A., Koch, F., ... Pedo, T. (2018). Nitrogen fertilization on maize sowing: Plant growth and seed vigor. American Journal of Plant Sciences, 9 , 83-97. https://doi.org/10.4236/ajps.2018.91008

Vieira, R. D., \& Krzyzanowski, F. C. (1999). Teste de condutividade elétrica. In F. C. Krzyzanowski, R. D. Vieira, \& J. B. França Neto (Eds.), Vigor de sementes: Conceitos e testes (Cap. 4, pp. 1-26). Londrina: ABRATES.

West, S. H., \& Harris, H. C. (1963). Seed coat colors associated with physiological changes in alfafa and crimson and white clovers. Crop Science, 3, 190-193. https://doi.org/10.2135/cropsci1963.0011183X0003000 $30005 x$

Zanatta, E., Szareski, V. J., Carvalho, I. R., Pimentel, J. R., Troyjack, C., Dellagostin, S. M., Demari, G. H., ... Aumonde, T. Z. (2018). Pre-harvest Desiccation: Productivity and Physical and Physiological Inferences on Soybean Seeds during Storage. Journal of Agricultural Science, 10(6), 354-362. https://doi.org/10.5539/ jas.v10n6p354

\section{Copyrights}

Copyright for this article is retained by the author(s), with first publication rights granted to the journal.

This is an open-access article distributed under the terms and conditions of the Creative Commons Attribution license (http://creativecommons.org/licenses/by/4.0/). 